\title{
Cytotoxicity of Quercetin and Quercetin-3-O-rhamnoside of Etlingera elatior (Jack) R.M.Sm. leaves against HeLa Cervical Cancer Cells
}

\author{
Kusriani Herni ${ }^{1,2}$, Anas Subarnas ${ }^{1 *}$, Ajeng Diantini ${ }^{1}$, Yoppi Iskandar ${ }^{1}$ \\ ${ }^{1}$ Faculty of Pharmacy, Padjadjaran University, Sumedang, Indonesia \\ ${ }^{2}$ Faculty of Pharmacy, Bhakti Kencana University, Bandung, Indonesia
}

\begin{tabular}{|c|c|}
\hline ARTICLE INFO & ABSTRACT \\
\hline $\begin{array}{l}\text { Received on: } 11 / 09 / 2020 \\
\text { Accepted on: } 23 / 12 / 2020 \\
\text { Available online: } 05 / 05 / 2021\end{array}$ & $\begin{array}{l}\text { Etlingera elatior traditionally used for therapeutic purposes. Pharmacological activities of this plant have been } \\
\text { reported, one of which is cytotoxic activity. This study aims to isolate cytotoxic compounds against HeLa cervical } \\
\text { cancer cell lines from an ethanol extract of the E. elatior leaves. The isolation work was conducted by means of column } \\
\text { chromatography and determination of the molecular structure was by spectroscopic data analysis. The cytotoxicity }\end{array}$ \\
\hline $\begin{array}{l}\text { Key words: } \\
\text { Etlingera elatior (Jack) } \\
\text { R.M.Sm., HeLa cell, } \\
\text { quercetin, quercetin-3-O- } \\
\text { rhamnoside. }\end{array}$ & $\begin{array}{l}\text { was determined by the 3-(4,5-dimethylthiazol-2-yl)-2,5- diphenyltetrazolium bromide (MTT) method. The results of } \\
\text { this study were two isolated compounds identified as quercetin and quercetin-3-O-rhamnoside from the ethyl acetate } \\
\text { fraction. These two compounds had cytotoxic activity on HeLa cervical cancer cells which was indicated by the } \\
\text { inhibition of cell proliferation with } \mathrm{IC}_{50} \text { values were } 29.49 \text { and } 46.67 \mu \mathrm{g} / \mathrm{mL} \text {, respectively. In the migration assay, } \\
\text { quercetin and quercetin-3-O-rhamnoside inhibited migration of the HeLa cells significantly at } 10 \mu \mathrm{g} / \mathrm{mL} \text { as compared } \\
\text { with the control, in } 24 \text { and } 48 \mathrm{hr} \text { experiments. This study reinforces the previous evidence of the potential of quercetin } \\
\text { and quercetin-3-O-rhamnoside as an anticancer drug candidate. }\end{array}$ \\
\hline
\end{tabular}

\section{INTRODUCTION}

Etlingera elatior (torch ginger) is a species of the Zingiberaceae, and is an edible native Indonesian plant, Malaysia, and other countries in Southeast Asia ( Chan et al., 2011; Lachumy et al., 2010). Its flowers are commonly used as spices for food and vegetable, and also used for medicinal purposes (Chan et al., 2007; Lachumy et al., 2010; Shahid and Basher, 2019). Its leaves are usually applied topically as antiseptics to clean wounds (Ibrahim and Setyowati, 1999) and used in a mixture with other fragrant herbs to deal with body odor (Chan et al., 2007). Torch ginger leaves also has been reported to contain flavonoid, tannin, triterpenoid, saponin, and carbohydrates (Lachumy et al., 2010). The flavonoid compounds in E. elatior were identified as quercetin, apigenin, kaempferol, luteolin, and myrcetin (Ghasemzadeh et al., 2015) and the main content of essential oil consist of $\beta$-pinene,

"Corresponding Author

Anas Subarnas, Faculty of Pharmacy, Padjadjaran University, Sumedang, Indonesia, E-mail: aasubarnas@yahoo.co.id dodecene, and sesquiterpenes of $\beta$-farnesene, and caryophylelene (Abdelwahab et al., 2010; Chan et al., 2010).

Several studies on pharmacological activities of E. elatior have reported that this species has various kinds of activities, including antibacterial, antioxidant, antifungal, tyrosinase inhibition, hepatoprotector, and cytotoxic activity (Chan et al., 2011; Ghasemzadeh et al., 2015, Kusriani et al., 2017). The rhizome of this plant can inhibit tumor growth in the Epstein-Barr virus early antigen test; flower extracts showed antiproliferative activity against breast cancer cells, and leaf extracts showed an antioxidant and cytotoxic activity on HeLa cells (Habsah et al., 2005; Lachumy et al., 2010; Shaikh et al., 2016)

Our study on E. elatior has successfully isolated and identified quercetin and quercetin-3-O-rhamnoside (quercitrin). Evidence is available concerning the cytotoxicity of quercetin on various kinds of cancer cells, such as cervical, breast, lung, colorectal, prostate, and nasopharyngeal cancer (Shafabakhsh and Asemi, 2019). However, reports on their cytotoxicity on cervical cancer cells are limited. In this study, we evaluated quercetin and quercetin-3-O-rhamnoside for their cytotoxicity against cervical cancer cells and their effect on cell migration. 


\section{MATERIALS AND METHODS}

\section{General procedures}

UV spectra were measured using Shimadzu spectrophotometer UV 1,800 (Kyoto, Japan). The IR spectrum was analyzed with the IR Spectrometer instrument by PerkinElmer ${ }^{\mathbb{R}}$ (Waltham, MA). Nuclear Magnetic Resonance (NMR) spectra were analyzed with the Agilent ${ }^{\circledR}$ DD2 series console spectrophotometer at $500(1 \mathrm{H})$ and $125(13 \mathrm{C}) \mathrm{MHz}$ using acetone as the solvent. The column chromatography process was carried out with silica gel 60 (70-230 Mesh ASTM; Merck, Darmstadt, Germany) as a stationary phase. Thin-layer chromatography was performed on precoated silica gel $60 \mathrm{PF}_{254}$ plates (Merck, Darmstadt, Germany). A universal spray reagent, sulfuric acid $10 \%$, was used to detect the chromatogram. All solvents for the separation process are technical solvents which have been previously distilled off.

\section{Plant materials}

Etlingera elatior (Jack) R.M.Sm. leaves were collected from local gardens in Bandung, West Java, Indonesia. The plant was authenticated in the herbarium of the Department of Biology, Padjadjaran University, Indonesia. Leaves were cleaned under running water, sliced to reduce the sample size, and oven-dried at $40^{\circ} \mathrm{C}$ until a constant weight.

\section{Chemicals and reagents}

Roswell Park Memorial Institute 1,640 medium (cat no. 11875093), fetal bovine serum (FBS) (cat no. 10270106), dimethyl sulfoxide (DMSO) (cat no. D8418), and 3-(4,5-dimethylthiazol2-yl)-2,5 diphenyl tetrazolium bromide (MTT) (cat. no. M2128) were purchased from Sigma-Aldrich, St. Louis, MO. Doxorubicin was provided by the Laboratory of Cell Culture and Cytogenetic, Faculty of Medicine, University of Padjadjaran, Indonesia. All chemical reagents were of analytical grade.

\section{Cell culture and conditions}

HeLa cell lines (human cervix carcinoma) were used to investigate the cytotoxic activity of leaves extract, fractions, and isolate of the E. elatior leaves. HeLa cells were cultured in Roswell Park Memorial Institute (RPMI) as a medium ( $\mathrm{pH} 7.4)$, which was added to $10 \% \mathrm{FBS}$, penicillin $(100 \mathrm{U} / \mathrm{ml})$, and streptomycin sulfate $(100 \mathrm{mg} / \mathrm{ml})$. All experiments were conducted in triplicate at the Laboratory of Cell Culture and Cytogenetic of the Faculty of Medicine, University of Padjadjaran, Indonesia.

\section{Extraction and isolation}

The powders of the E. elatior leaves $(2,000 \mathrm{~g})$ were extracted with ethanol $70 \%$ (3x, each 24 hours) by the maceration method. The extract was concentrated using a rotary evaporator at $60^{\circ} \mathrm{C}$ to produce a concentrated extract $(570 \mathrm{~g})$, and the concentrated extract was fractionated with a mixture of water : hexane $(3: 1)$ to produce a layer of hexane and water. The water layer was then repartitioned with etOAc to produce an etOAc and $\mathrm{H}_{2} \mathrm{O}$ layer, and finally, the $\mathrm{H}_{2} \mathrm{O}$ layer was partitioned with $\mathrm{buOH}$ to produce buOH and aqueous layers. The four layers were evaporated to produce an n-hexane fraction $(3.16 \mathrm{~g})$, etOAc fraction $(106.6 \mathrm{~g})$, buOH fraction $(116.83 \mathrm{~g})$, and $\mathrm{H}_{2} 0$ fraction $(248.92 \mathrm{~g})$. The extract and all fractions were tested for cytotoxic activity against HeLa cell lines by MTT test. Among the four fractions, the ethyl acetate exhibited the highest cytotoxicity, so further work was focused on the ethyl acetate fraction to isolate active compounds. Subsequently, the ethyl acetate fraction was then separated again by column chromatography with silica gel and eluted with a mixture of n-hexane and ethyl acetate with various ratios to increase polarity (n-hexane to ethyl acetate, 9:1, $8: 2,7: 3,6: 4$, and 5:5), resulting in several subfractions. Fraction 2 of the nine fractions was repeatedly column chromatographed with silica gel and the eluent of the chloroform methanol-water mixtures to result in a pure compound 1 (103 mg). Fraction 6 was carried out by column chromatography with silica gel and eluted with $\mathrm{CHCl}_{3}: \mathrm{MeOH}(9: 1)$ to produce one isolate, which was purified into pure compound $\mathbf{2}(30 \mathrm{mg})$. The two compounds were identified by spectral UV, IR, MS, and $1 \mathrm{H}$ and 13C NMR data.

\section{Cytotoxicity examination in MTT assay}

The cytotoxicity of the extract, fractions, and compounds that have been isolated against cells of HeLa cervical cancer was tested by the MTT assay (Mosmann, 1983). The 3,000 cells per well were seeded in a 96-well microtiter with $100 \mathrm{~mL}$ RPMI medium. Next, cells were incubated for 24 hours at $37^{\circ} \mathrm{C}$ under $5 \% \mathrm{CO}_{2}$ in a humid atmosphere. Then, the RPMI media were discarded and fresh media containing extracts and fractions with different doses were added. After an incubation period, the media were removed. To each well, $20 \mu \mathrm{l}$ of MTT ( $5 \mathrm{mg} / \mathrm{ml} \mathrm{pH} \mathrm{4.7)} \mathrm{was} \mathrm{added} \mathrm{and} \mathrm{then}$ incubated again for 4 hours. The supernatant liquid was removed. $100 \mu 1$ of DMSO as a stopper reaction was added and shaken for 15 minutes. The absorbance was measured at $550 \mathrm{~nm}$ using a plate reader (Thermo Scientific ${ }^{\circledR}$ Multiscan EX, Singapore). All experiments were carried out in triplicate. The absorbance of cells without a sample is considered to be $100 \%$. The $50 \%$ inhibition concentration $\left(\mathrm{IC}_{50}\right)$ was determined by a graph.

\section{Migration assay}

Cell migration was observed with a 24-well Transwell plate system (Costar, Corning, USA) in the scratch/wound-healing assay in HeLa cell lines. HeLa cells were grown in 24-well plates and were treated or untreated with quercetin, quercetin 3-O rhamnoside, and doxorubicin (a positive control) in the complete medium and then placed in the incubator. After 24 hours of incubation, gaps were introduced with a P10 pipette tip by gently scraping the monolayer. After scrapping, to remove debris, cells were washed with Phosphate Buffered Saline thrice. Cells that have been given the gap were incubated for 0,24 , and 48 hours at $37^{\circ} \mathrm{C}\left(5 \% \mathrm{CO}_{2}\right)$ (Cory, 2011). The treatments were observed with a microscope linked to a computer and ToupView software (version x64, 3.7.7892) and documented as TIFF, and gap areas were measured with ImageJ (NIH). The experiments were carried out in triplicate (Schneider et al., 2012)

\section{RESULTS AND DISCUSSION}

\section{Cytotoxicity of E. elatior leaves}

The extract and fractions of the E. elatior leaves were tested for their 24 hours effects against HeLa cancer cell lines using the MTT bioassay; results are shown in Figure $1 . \mathrm{IC}_{50}$ values of all samples are presented in Table 1. Among all the samples tested, the extract had the strongest inhibition against the HeLa cell lines 
proliferation, followed by ethyl acetate, butanol, n-hexane, and water fractions with $\mathrm{IC}_{50}$ of $127.98,156.47,225.68,312.47$, and $561.58 \mu \mathrm{g} / \mathrm{ml}$, respectively. A further study was conducted on the ethyl acetate fraction to explore active compounds responsible for their cytotoxicity.

\section{Identification of Compound 1 and Compound 2}

The ethyl acetate fraction which had cytotoxicity against the HeLa cell lines in the MTT assay was subjected to repeated column chromatography and two compounds, compounds $\mathbf{1}$ and $\mathbf{2}$, were isolated. Both compounds were identified in their spectral data.

\section{Compound 1}

Compound 1 was the crystal of yellow color with a melting point variously reported of $309-314^{\circ} \mathrm{C}$ and showed a molecular ion peak at $\mathrm{m} / z 303.05$ with Electron Ionization-Mass Spectrometry. The MS and NMR data indicated that the molecular formula of compound 1 is $\mathrm{C}_{15} \mathrm{H}_{10} \mathrm{O}_{7}$.

Two maximum absorption peaks of the UV spectrum were shown at a wavelength of $363 \mathrm{~nm}$ and $282 \mathrm{~nm}$. It is specific for flavonol spectrum from flavonoids (Mabry et al., 1970). The IR spectrum showed the presence of hydroxyl $(3,450,3,255,1,400$, and $\left.1,320 \mathrm{~cm}^{-1}\right)$, carbonyl $\left(1,606 \mathrm{~cm}^{-1}\right)$, alkene $\left(1,562 \mathrm{~cm}^{-1}\right)$, and aromatic $\left(1,458 \mathrm{~cm}^{-1}\right)$ groups in the molecule.

The ${ }^{1} \mathrm{H}$ NMR data of the compound 1 revealed five aromatic proton signals at $\delta 6.26(1 \mathrm{H}, \mathrm{d}, J=2.0 \mathrm{~Hz}), 6.51(1 \mathrm{H}, \mathrm{d}, J$

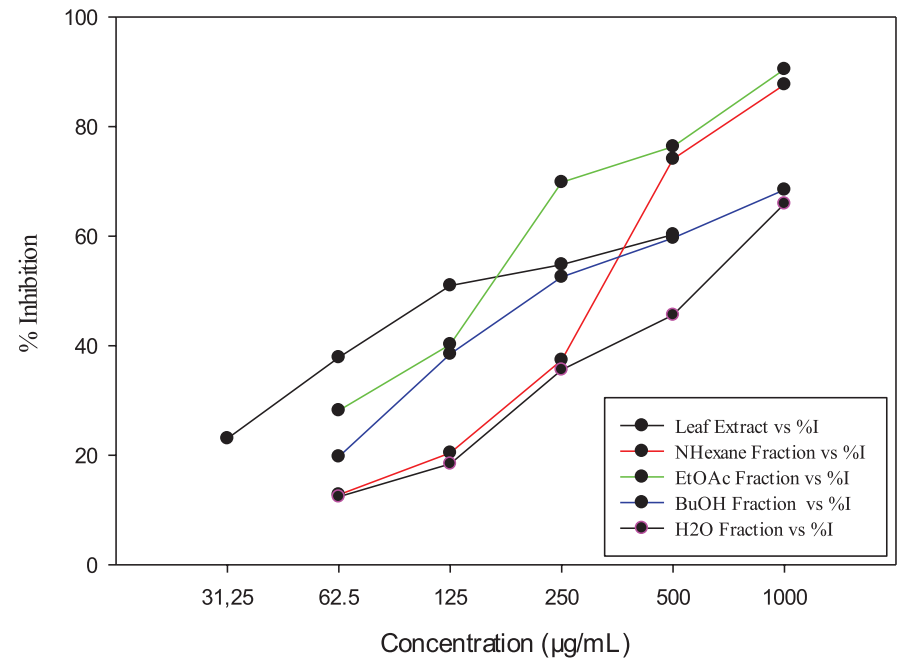

Figure 1. Inhibition of ethanol extract and fractions of E. elatior leaves against HeLa cancer cells.

Table 1. $\mathrm{IC}_{50}$ of extract and fractions of E. elatior leaves against HeLa cell lines.

\begin{tabular}{cc}
\hline Samples & $\mathbf{I C}_{\mathbf{5 0}}\left(\boldsymbol{\mu \mathrm { g } / \mathbf { m l } ^ { - 1 } ) ^ { \mathbf { a } }}\right.$ \\
\hline Extract & $127.98 \pm 2.83$ \\
$n$-Hexane fraction & $312.47 \pm 4.01$ \\
EtOAc fraction & $156.47 \pm 4.12$ \\
Butanol fraction & $225.68 \pm 2.74$ \\
Water fraction & $561.58 \pm 3.08$ \\
\hline
\end{tabular}

$\mathrm{IC}_{50}$ values were analyzed with SigmaPlot ver. 12 and a four-parameter logistic model. ${ }^{a}$ Data are presented as mean $\pm \mathrm{SD}$ of triplicate.
$=2.0 \mathrm{~Hz}), \delta 7.00(1 \mathrm{H}, \mathrm{d}, J=8.5 \mathrm{~Hz}), 7.70(1 \mathrm{H}, \mathrm{dd}, J=8.5 ; 2.0 \mathrm{~Hz})$, and $7.82(1 \mathrm{H}, \mathrm{d}, J=2.0 \mathrm{~Hz})$, which showed that this compound has 1,3,4-tri- and 1,2,3,5-tetrasubstitutes in benzene. There are two doublet signals at $\delta 6.26$ and 6.51 and their characteristics were derived from $\mathrm{H}-6$ and $\mathrm{H}-8$ of a flavonol containing a 5,7-dihydroxy substitution pattern of the A ring, whereas the signals appearing at $\delta 7.00,7.70$, and 7.82 were assumed to be attributed to H-5', H-6', and $\mathrm{H}-2^{\prime}$, respectively, of the B-ring of the flavonol. Furthermore, a downfield peak at $\delta 12.16(1 \mathrm{H}, s)$ was a characteristic signal of the hydroxyl proton of $\mathrm{C}-5$. These ${ }^{1} \mathrm{H}$ NMR spectral data suggested that compound $\mathbf{1}$ was quercetin. This assumption was supported by the ${ }^{13} \mathrm{C}$ NMR spectra, which indicates the presence of 15 signals consisting of 14 signals at $\delta 94.45-164.98 \mathrm{ppm}$ of aromatic carbons of benzene rings and one signal derived from a carbonyl carbon at $\delta 176.55 \mathrm{ppm}$. Comparison of all NMR spectral data with the reported evidence (Aisyah et al., 2017) confirmed that compound $\mathbf{1}$ is quercetin (Fig. 2).

\section{Compound 2}

Compound 2 was a yellow amorphous powder. The molecular ion peak was at $m / z 471.08[\mathrm{M}+\mathrm{Na}]$. This molecular ion peak together with the number of hydrogens and carbons in ${ }^{1} \mathrm{H}$ and ${ }^{13} \mathrm{C}$ NMR data indicated that the molecular formula of this compound was $\mathrm{C}_{21} \mathrm{H}_{20} \mathrm{O}_{11}$. Its $\mathrm{UV}$ spectrum showed strong absorbance at 350 and $256 \mathrm{~nm}$. These absorbance values are<smiles>O=c1c(O)c(-c2ccc(O)c(O)c2)oc2cc(O)cc(O)c12</smiles>

Figure 2. Quercetin.

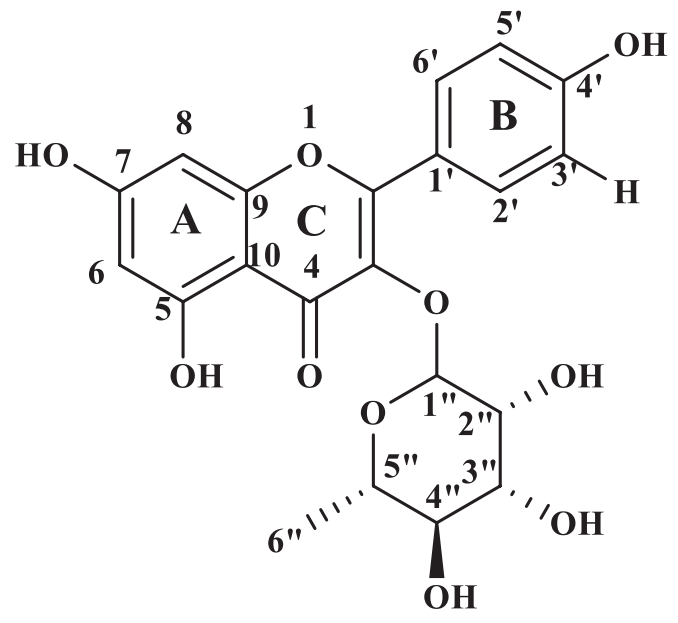

Figure 3. Quercetin-3-0-rhamnoside. 


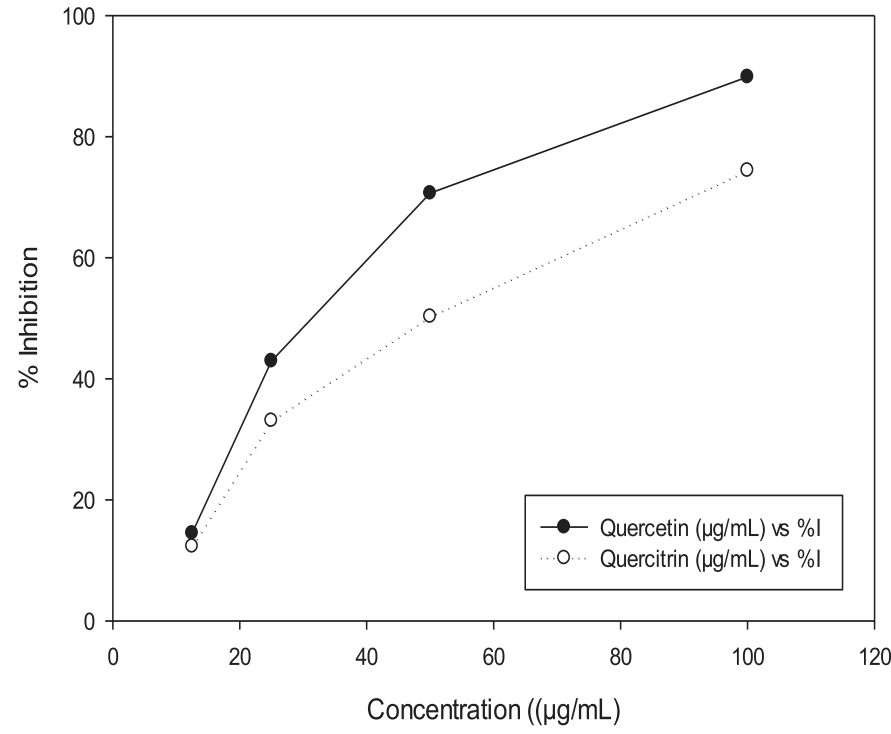

Figure 4. Inhibition of quercetin and quercetin-3-O-rhamnoside of E. elatior against HeLa cancer cells.

Table 2. $\mathrm{IC}_{50}$ of quercetin and quercitrin of E. elatior leaves against $\mathrm{HeLa}$ cell lines.

\begin{tabular}{cc}
\hline Samples & $\mathbf{I C}_{50}\left(\boldsymbol{\mu g} / \mathrm{ml}^{-1}\right)^{\mathbf{a}}$ \\
\hline Quercetin & $29.49 \pm 1.35$ \\
Quercitrin & $46.67 \pm 1.97$ \\
\hline
\end{tabular}

$\mathrm{IC}_{50}$ of each sample was analyzed with SigmaPlot ver. 12 and a four-parameter logistic model.

a Data are presented as mean \pm SD of triplicate. characteristic of a flavonol skeleton glycosylated at the 3-hydroxyl group. The infrared spectrum showed the presence of the functional groups of hydroxyl $\left(3,271 \mathrm{~cm}^{-1}\right)$, carbonyl $\left(1,652 \mathrm{~cm}^{-1}\right)$, alkene $\left(1,556 \mathrm{~cm}^{-1}\right)$, and aromatic ring $\left(1,456 \mathrm{~cm}^{-1}\right)$.

${ }^{1} \mathrm{H}$ NMR spectra of compound 2 showed coupling patterns similar to compound $\mathbf{1}$. Aromatic proton signals appearing at $\delta 6.40(1 \mathrm{H}, d, J=2.0 \mathrm{~Hz})$ and $6.50(1 \mathrm{H}, d, J=2.0 \mathrm{~Hz})$ were derived from H-6 and H-8 of a flavonol with the 5,7-dihydroxy substitution, whereas those at $\delta 6.9(1 \mathrm{H}, \mathrm{d}), 7.30(1 \mathrm{H}, d d, J=8.4$; $2.1 \mathrm{~Hz})$, and $7.48(1 \mathrm{H}, d, J=2.1 \mathrm{~Hz})$ were, respectively, generated from H-5', H-6', and H-2' of the B-ring. The characteristic signal of hydroxyl proton at C-5 is a downfield peak at $\delta 12.68(1 \mathrm{H}, s)$. In this ${ }^{1} \mathrm{H}$ NMR spectrum, the anomeric proton signal was shown at $\delta$ $5.47(1 \mathrm{H}, d, J=1.2)$ along with four proton signals of oxygenated methines at $\delta 3.00-4.35 \mathrm{ppm}$ and one methyl proton signal at $\delta 0.90$ $(3 \mathrm{H}, s)$. These proton signals were derived from a sugar moiety, the sugar of which was supposed to be rhamnose, and this assumption was supported by the ${ }^{13} \mathrm{C}$ NMR data which showed five oxygenated methine carbons at $\delta 102.80,72.94,72.02,71.44$, and 71.32 and one methyl carbon at $\delta$ 17.73. In addition, the ${ }^{13} \mathrm{C}$ NMR spectrum showed 14 signals at $\delta$ 99.50-163.07 ppm of aromatic carbons of benzene rings and one signal derived from a carbonyl carbon at $\delta$ $179.20 \mathrm{ppm}$. Hence, this compound was assumed to be quercetin3-O-rhamnoside or quercitrin (Fig. 3), confirmed by comparison with previously reported NMR spectral data (Utari et al., 2019)

\section{Cytotoxicity of quercetin and quercetin-3-0-rhamnoside against HeLa cancer cell lines}

Quercetin and quercetin-3-0-rhamnoside (quercitrin) were examined for cytotoxicity effects on HeLa cancer cells with
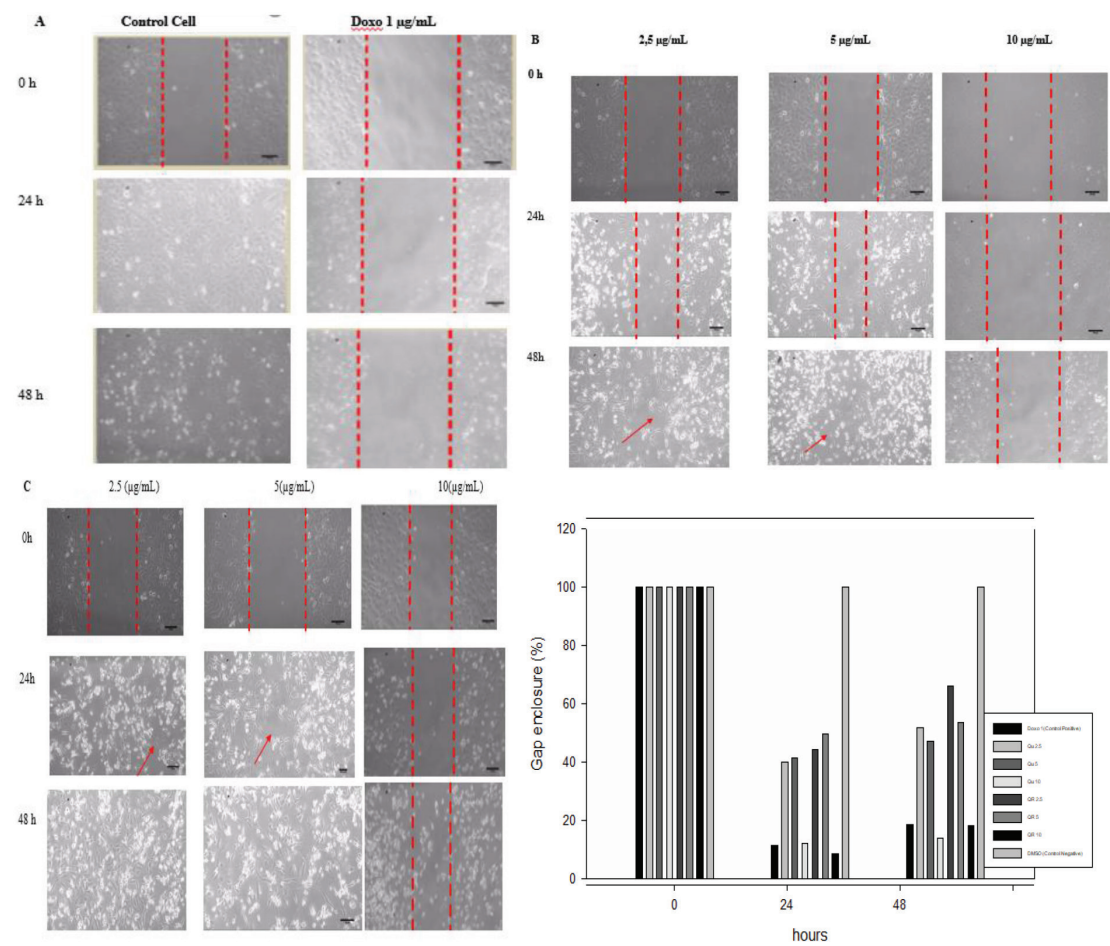

Figure 5. Effect of doxorubicin (A), quercetin (B), and quercetin 3-O-rhamnoside (C) on cell migration in HeLa cell lines. Figures A, B, and C are representative migration photographs of HeLa cells with doxorubicin (A), quercetin (B), and quercetin 3-O-rhamnoside (C). HeLa cells were untreated and treated samples for 24 and $48 \mathrm{~h}$. Quantification gap enclosure (\% area) of HeLa cells (D). The values are presented as mean $\pm \mathrm{SD}(n=3), p<0.05$ to control. 
MTT bioassay in a 24-hours examination (Fig. 4) and the $\mathrm{IC}_{50}$ value is shown in Table 2. Figure 4 shows that both quercetin and quercitrin can inhibit the growth of HeLa cells at certain doses, which demonstrated that $\mathrm{IC}_{50}$ values were, respectively, 29.49 and $46.67 \mu \mathrm{g} / \mathrm{ml}$.

\section{Inhibitory effect of quercetin and quercetin-3-0-rhamnoside on cell migration}

Quercetin (2.5, 5.0, and $10.0 \mu \mathrm{g} / \mathrm{ml})$, quercetin 3-O-rhamnoside $(10.0,15.0$, and $20.0 \mu \mathrm{g} / \mathrm{ml})$, and doxorubicin $(1.0 \mu \mathrm{g} / \mathrm{ml})$ were evaluated after 24 and 48 hours incubations for their effects on cell migration of the HeLa cell lines by a woundhealing assay (Fig. 5). All samples tested showed the inhibition of cell migration at 24- and 48-hours experiments, but in the 48 hours, their effects were decreased. Quercetin and quercetin 3-O-rhamnoside showed concentration-dependent inhibitory effects and the significant effect $(p<0.05)$ was shown by the concentration of $10.0 \mu \mathrm{g} / \mathrm{ml}$.

\section{DISCUSSION}

Quercetin and quercetin-3-O-rhamnoside are flavonoid compounds derived from nature and are widely found in daily foods. In this study, these isolated compounds from the E. elatior leaves by a means of cytotoxicity bioassay-guided fractionation and their molecular structures were determined from their spectroscopic data. Their cytotoxicity in HeLa cervical cancer cells were evaluated along with its inhibitory effect on cell migration. The isolation of quercetin and quercetin-3-O-rhamnoside from the E. elatior leaves and evaluation of their cytotoxic activity were reported for the first time.

Quercetin and quercetin-3-O-rhamnoside showed cytotoxic activity in a concentration-dependent manner against HeLa cell lines, which was indicated by their inhibition of cell proliferation as shown in Table 2. These two compounds had higher inhibitory activity against cell proliferation as compared to the active extract and ethyl acetate fraction (Table 1). This may be due to the fact that the extract and the ethyl acetate fraction contain diverse compounds of nonspecific chemical substances that may interact with each other and decrease the activity. Quercetin decreased cell viability with the $\mathrm{IC}_{50}$ value of $29.49 \mu \mathrm{g} / \mathrm{ml}$ lower than that of quercetin-3-O-rhamnoside $(46.67 \mu \mathrm{g} / \mathrm{ml})$, revealing that quercetin had more potent cytotoxicity against cervical cancer cells. Quercetin as an aglycone which has higher lipophilic properties than quercetin-3-O-rhamnoside would be easier to penetrate the cell membrane, causing it higher cytotoxicity against cells.

It has been reported that quercetin can inhibit HeLa cell growth and induce apoptosis by influencing the cell cycle in the G0/G1 phase, downregulating the expression of bcl-2, PI3K, and p-Akt, upregulating Bax, increasing the action of caspases (Rauf et al., 2018), and suppressing cell viability with the initiation of the cell cycle arrest G2/M phase and apoptosis through a p53dependent mechanism (Priyadarsini et al., 2010).

Anticancer agents generally not only suppress the cancer cell growth but may also inhibit cell metastases. The inhibition activity of cancer cells in migration plays an important role in cancer development and progression. The inhibition of cell migration to the formation of a wound or gap was examined with scratch wound assay (Cory, 2011). In this study, quercetin and quercetin-3-O-rhamnoside evaluated for their inhibition on the migration of the HeLa cancer cell lines inhibited migration of the cells significantly at the concentration of $10 \mu \mathrm{g} / \mathrm{ml}$ when compared to controls, in the 24- and 48-hours experiments. The increasing concentrations increased their inhibitory effects, while the longer the incubation time, their effects were decreased. Quercetin has been reported to inhibit cell migration and invasion of several cancer cells, such as glioblastoma cells (Levesque et al., 2012), oral cancer cells (Lai et al., 2013), melanoma cells (Cao et al., 2015), breast cancer (Li et al., 2017), and hepatocellular carcinoma (Lu et al., 2018). Inhibition of cell migration and invasion is caused by inhibition of MMP-2/MMP9 (Lai et al., 2013) through the signal transduction pathway on PI3K/Akt (Lu et al., 2018). One of the matrix metalloproteinase (MMP) families is MMP-2/MMP-9 metalloproteinase (MMP), which plays a role in migration, invasion, and metastasis in various types of cancer ( $\mathrm{Lu}$ et al., 2018). Hence, quercetin and quercetin-3-O-rhamnoside may have potential as cancer drug candidates that could be able to prevent the spread of cancer cells in the body.

\section{CONCLUSION}

Our research provided findings that quercetin and quercetin-3-O-rhamnoside isolated from the E. elatior leaves showed cytotoxic activity and inhibited cell migration against the HeLa cells line. These findings support previous evidence that quercetin and its derivative has the potential for therapeutic application in cancer treatment, including cervical cancer treatment.

\section{ACKNOWLEDGMENTS}

Authors are thank to Bhakti Kencana University for providing financial assistance and Padjadjaran University for supporting this reseach. And thanks to Dr. Ahmad Faried, MD., SPBS., PhD., Dr. med. Hasan Bashari, dr., M.Kes., Tenny Putri Wikayani, S.ST and Nurul Qomarilla, SKM. for providing and handling HeLa cell lines in the Cell Culture and Cytogenic Laboratory, Faculty of Medicine, Padjadjaran University.

\section{AUTHOR CONTRIBUTIONS}

All authors made substantial contributions to conception and design, acquisition of data, or analysis and interpretation of data; took part in drafting the article or revising it critically for important intellectual content; agreed to submit to the current journal; gave final approval of the version to be published; and agree to be accountable for all aspects of the work. All the authors are eligible to be an author as per the international committee of medical journal editors (ICMJE) requirements/guidelines.

\section{FUNDING}

There is no funding to report.

\section{CONFLICTS OF INTEREST}

The authors report no financial or any other conflicts of interest in this work.

\section{ETHICAL APPROVALS}

This study does not involve experiments on animals or human subjects. 


\section{PUBLISHER'S NOTE}

This journal remains neutral with regard to jurisdictional claims in published institutional affiliation.

\section{REFERENCES}

Abdelwahab SI, Zaman FQ, Mariod AA, Yaacob M, Abdelmageed AHA, Khamis S. Chemical composition, antioxidant and antibacterial properties of the essential oils of Etlingera elatior and Cinnamomum pubescens Kochummen. J Sci Food Agric. 2010; 90(15):2682-8

Aisyah LS, Yun YF, Herlina T, Julaeha E, Zainuddin A, Nurfarida I, Hidayat T, Supratman U, Shiono Y. Flavonoid compounds from the leaves of Kalanchoe prolifera and their cytotoxic activity against P-388 Murine Leukaemia Cells. Nat Prod Sci, 2017; 23(2):139-45.

Cao HH, Cheng CY, Su T, Fu XQ, Guo H, Li T, Kai-Wing Tse A, Kwan HY, Yu H, Yu ZL. Quercetin inhibits HGF/c-Met signaling and HGFstimulated melanoma cell migration and invasion. Mol Cancer, 2015; 14:103.

Chan EWC, Lim YY, Nor Azah MA. Composition and antibacterial activity of essential oils from leaves of Etlingera species (Zingiberaceae). Int J Adv Sci Art, 2010; 1(2):1-12.

Chan EWC, Lim YY, Omar M. Antioxidant and antibacterial activity of leaves of Etlingera species (Zingiberaceae) in peninsular Malaysia. Food Chem, 2007; 104:1586-93.

Chan EWC, Lim YY, Wong SK. Phytochemistry and pharmacological properties of Etlingera elatior: a review. Pharmacogn J, 2011;3(22):6-10.

Cory G. Scratch-wound assay. In: Wells C, Parsons M. (eds.). Cell migration. Methods in molecular biology (methods and protocols). Totowa, NJ: Humana Press, p 769, 2011.

Ghasemzadeh A, Jaafar HZE, Rahmat A, Ashkani S. Secondary metabolites constituents and antioxidant, anticancer and antibacterial activities of Etlingera elatior (Jack) R. M. Sm grown in different locations of Malaysia. Int Soc Complement Med Res, 2015; 15:335.

Habsah M, Lajis NH, Sukari MA, Yap YH, Kikuzaki H, Nakatani N. Antitumor-promoting and cytotoxic constituents of Etlingera elatior. Malays J Med Sci, 2005; 12(1) 6-12.

Ibrahim H, Setyowati FM. Etlingera. In: de Guzman CC, Siemonsma JS (eds.). Plant resources of South-East Asia. Pudoc, Wageningen, Netherlands, pp 123-6, 1999.

Kusriani H, Subarnas A, Diantini A, Iskandar Y, Marpaung S, Juliana M, Silalahi F. Antioxidant and cytotoxic activities, total phenolic content of leaf, flower, and rhizome extract of thorch ginger (Etlingera elatior). Pharmacy 2017;14(01):51-63.

Lachumy SJT, Sasidharan S, Sumathy V, Zuraini Z. Pharmacological activity, phytochemical analysis and toxicity of methanol extract of Etlingera elatior (torch ginger) flowers. Asian Pac J Trop Med, 2010; 3(10):769-74.

Lai WW, Hsu SC, Chueh FS, Chen YY, Lin JP, Lien JC, Tsai $\mathrm{CH}$, Chung JG. Quercetin inhibits migration and invasion of SAS human oral cancer cells through inhibition of NF-kappaB and matrix metalloproteinase-2/-9 signaling pathways. Anticancer Res, 2013; $33: 1941-50$.
Levesque JM, Bousquet-Gagnon N, Beliveau R. Quercetin abrogates IL-6/STAT3 signaling and inhibits glioblastoma cell line growth and migration. Exp Cell Res, 2012; 318:925-35.

Li J, Zhang J, Wang Y, Liang X, Wusiman Z, Yin Y, Shen Q. Synergistic inhibition of migration and invasion of breast cancer cells by dual docetaxel/quercetin-loaded nanoparticles via Akt/MMP-9 pathway. Int J Pharm, 2017; 523:300-9.

Lu J, Wang Z. Li S, Xin Q, Yuan M, Li H, Song X, Gao H, Pervaiz N, Sun X, Lu W, Jing T, Zhu Y. Quercetin inhibits the migration and invasion of HCCLM3 cells by suppressing the expression of p-Akt1, matrix metalloproteinase (MMP) MMP-2, and MMP-9. Med Sci Monit, 2018; 24:2583-9.

Mabry T, Markham KR, Thomas MB. The Systematic identification of flavonoids. New York, NY: Springer-Verlag Berlin Heidelberg, 1970; doi: 10.1007/978-3-642-88458-0

Mosmann T. Rapid colorimetric assay for cellular growth and survival: application to proliferation and cytotoxicity assays. J Immunol Methods, 1983; 65(1-2):55-63.

Priyadarsini RV, Murugan RS, Maitreyi S, Ramalingam K, Karunagaran D, Nagini S. The flavonoid quercetin induces cell cycle arrest and mitochondria-mediated apoptosis in human cervical cancer (HeLa) cells through p53 induction and NF-kB inhibition. Eur J Pharmacol, 2010; 649:84-91.

Rauf A, Imran M, Khan IA, Rehman MU, Gilani SA, Mehmood Z, Mubarak MS. Review: Anticancer potential of quercetin: A comprehensive review. Phytotherapy Research 2018; 32(11):2109-30.

Schneider CA, Rasband WS, Eliceiri KW. NIH image to imageJ: 25 years of image analysis. Nat Methods, 2012; 9(7):671-5.

Shafabakhsh R and Asemi Z. Quercetin: A natural compound for ovarian cancer treatment. Journal of Ovarian Research 2019;12(55):1-9.

Shahid Ud Daula AFM, Basher MA. Genus etlingera - a review on chemical composition and antimicrobial activity of essential oil. Acad J, 2019; 13(7):135-56.

Shaikh AM, Shrivastava B, Apte KG, Navale SD. Medicinal plants as potential source of anticancer agents: a review. J Pharmacogn Phytochem, 2016; 5(2):291-5.

Utari F, Itam A, Syafrizayanti S, Putri WH, Ninomiya M, Koketsu M, Tanaka K, Efdi M. Isolation of flavonol rhamnosides from Pometia pinnata leaves and investigation of $\alpha$-glucosidase inhibitory activity of flavonol derivatives. J Appl Pharm Sci, 2019; 9(08):053-65.

How to cite this article:

Herni K, Subarnas A, Diantini A, Iskandar Y. Cytotoxicity of quercetin and quercetin-3-O-rhamnoside of Etlingera elatior (Jack) R.M.Sm. leaves against HeLa cervical cancer cells. J Appl Biol Biotech 2021; 11(05):085-090. 